\title{
ASYNCHRONOUS TURNOVER OF THE THIN FILA- MENT PROTEINS, ACTIN, TROPOMYOSIN AND TROPONIN BY A CONTINUOUS DOUBLE ISOTOPE METHOD ${ }^{1}$
}

\author{
Ryuhei FunABIKI ${ }^{2}$ and R. G. CASSENS \\ Muscle Biology Laboratory, University of Wisconsin, \\ Madison, Wisconsin 53706, U.S.A.
}

(Received June 30, 1973)

\begin{abstract}
The relative turnover rate of protein components of the thin filament was measured by a continuous double isotope method. Both ${ }^{3} \mathrm{H}$-lysine and ${ }^{14} \mathrm{C}$-lysine were administered continuously in the diet to male adult rabbits for 7 days. On the 7 th day, the ${ }^{14} \mathrm{C}$-lysine was discontinued while the ${ }^{3} \mathrm{H}$-lysine was continued for 14 additional days. The relative turnover rate of the protein components was estimated from the ${ }^{3} \mathrm{H} /{ }^{14} \mathrm{C}$ ratios of the isolated protein of the same animal. From the different ratios of ${ }^{3} \mathrm{H} /{ }^{14} \mathrm{C}$ of each protein fraction, asynchronous turnover of the thin filament proteins (actin, tropomyosin and troponin) was concluded. The order of degree in relative turnover rate is as follows: troponin> tropomyosin $>$ actin.
\end{abstract}

NEUBERGER (2) suggested that "the metabolic activity of actin or myosin in the muscle fiber, or that of collagen for example, is not a continuous function but varies in a discontinuous manner and is dependent on morphologic changes of the structures with which these proteins are associated." DreYFus et al. (3) showed that the specific activity of myosin (following an injection of ${ }^{14} \mathrm{C}$-glycine into rats) remained constant for about 30 days and then decreased in rats on a $24 \%$ protein diet, but when the animals received a diet containing $45 \%$ protein, the radioactivity of myosin progressively decreased. They concluded that the myofibril displayed a definite life span of about 30 days. The myosin was thought to be in a state of relative inertness and its metabolic behavior was compared with that of haemoglobin. However, FunABIKI and KANDATSU (4) concluded from their work on the continuous administration of ${ }^{14} \mathrm{C}$-labeled chlorella

1 Preliminary report of this paper has been published (1).

2 船引龍平 Present address: Department of Agricultural Chemistry, Tokyo Noko University, Saiwai-cho, Fuchu-shi, Tokyo, Japan. 
protein acid hydrolyzate that the manner of turnover of actin could not be compared with that of blood globin. From studies on isotope incorporation into protein by a single administration of several ${ }^{14} \mathrm{C}$-labeled amino acids, VeLICK (5) estimated that the half life of actin was 67 days, tropomyosin was 27 days, heavy meromyosin was 80 days and light meromyosin was 20 days, in the rabbit. However, McManus and Mueller (6) concluded that the half-life was 29 days for both light and heavy meromyosin. Even though these authors estimated the turnover rate of muscle protein fractions, turnover type of muscle protein was not discussed and the problem of precursor and reutilization on estimation of the turnover rate of the protein was left to be solved. With a puls injection of ${ }^{14} \mathrm{C}$-phenylalanine, the shape of the specific radioactivity-time curve of myosin and actin was similar, although their level of specific radioactivity was different (7). It was difficult to distinguish the specific radioactivity-time curve of myosin from that of actin in experiments that utilized continuous administration of ${ }^{14} \mathrm{C}$-chlorella protein acid hydrolyzate to the rats for 55 days (8). By the observation of the slow but continuous loss of total activity of aspartate and glutamate isolated from myofibrillar protein in the rat with a single injection of ${ }^{14} \mathrm{C}$-sodium carbonate, MILLWARD (9) suggested the random breakdown of myofibrillar protein. EBASHI et al. (10) have proposed the fine structure of the thin filament and suggested the location of actin, tropomyosin and troponin on its structure.

We tried to clarify whether the protein components of thin filaments turnover in a synchronous or asynchronous manner.

SCHIMKE et al. (11) showed an asynchronous turnover of protein of the endoplasmic reticulum of rat liver by the double isotope method. This method identifies only two time points on a decay curve in the same protein in the same animal instead of establishing a number of time points along a decay curve. The assumptions involved in the use of the Schimke method are not applicable in the case of proteins of the myofibril in skeletal muscle because they do not follow the simple exponential decay kinetics by the single isotope administration (7). We developed "a continuous double isotope method" which is a modification of continuous isotope administration method to try to solve the question of asynchronous turnover of thin filament proteins.

\section{MATERIALS AND METHODS}

General procedure. Male adult New Zealand white rabbits were used and the experiment was conducted twice at different times. In experiment I, two animals, rabbit $A$ and rabbit $B$ weighing $2.5 \mathrm{~kg}$ and $2.7 \mathrm{~kg}$ were used. In experiment II, two animals rabbit $\mathrm{C}$ and rabbit $\mathrm{D}$, both weighing $3.5 \mathrm{~kg}$ were used. Aminals were fed on agar gel diet (12) and Purina rabbit chow (crude protein not less than $16 \%$, crude fiber not more than $20 \%$ and crude fat not more than $2 \%$ ). The agar gel diet had a composition of $8 \mathrm{~g}$ of dry basal diet which contained $20 \%$ 
casein, $32.15 \%$ starch, $32.15 \%$ sucrose monohydrate, $10 \%$ corn oil, $5 \%$ salt mixture, $0.5 \%$ vitamin mixture, $0.2 \%$ choline chloride and $6 \mathrm{~g}$ of $4 \%$ agar and $2 \mathrm{ml}$ of labeled solutions. The $2 \mathrm{ml}$ of labeled solution was composed of $1 \mathrm{ml}$ each of the following solutions. One labeled solution contained $20 \mu \mathrm{Ci}$ of $\mathrm{L}^{-14} \mathrm{C}-(\mathrm{U})-$ lysine per $\mathrm{ml}$ of $0.05 \%$ dehydroacetic acid sodium salt aqueous solution. The other labeled solution contained $100 \mu \mathrm{Ci}$ of $\mathrm{L}^{-3} \mathrm{H}-(\mathrm{G})$-lysine per $\mathrm{ml}$ of $0.05 \%$ dehydroacetic acid sodium salt aqueous solution. The $\mathrm{L}_{-}{ }^{3} \mathrm{H}-(\mathrm{G})$-lysine (3.91 $\mathrm{Ci} / \mathrm{mmole})$ and $\mathrm{L}^{-14} \mathrm{C}-(\mathrm{U})$-lysine $(225 \mathrm{mCi} / \mathrm{mmole})$ were obtained from $\mathrm{New}$ England Nuclear. Scheme I shows the design of isotope administration. On the 7 th day after the start of isotope administration, rabbit $B$ and rabbit $D$ received the agar gel diet containing $1 \mathrm{ml}$ of ${ }^{3} \mathrm{H}$-lysine solution and $1 \mathrm{ml}$ of $\mathrm{H}_{2} \mathrm{O}$ instead of $1 \mathrm{ml}$ of ${ }^{14} \mathrm{C}$-lysine solution. The animals consumed the agar gel diet completely everyday throughout the feeding period even though Purina rabbit chow diet was fed ad libitum. The body weight changes during the experiments did not exceed more than $10 \%$ in all the animals used.

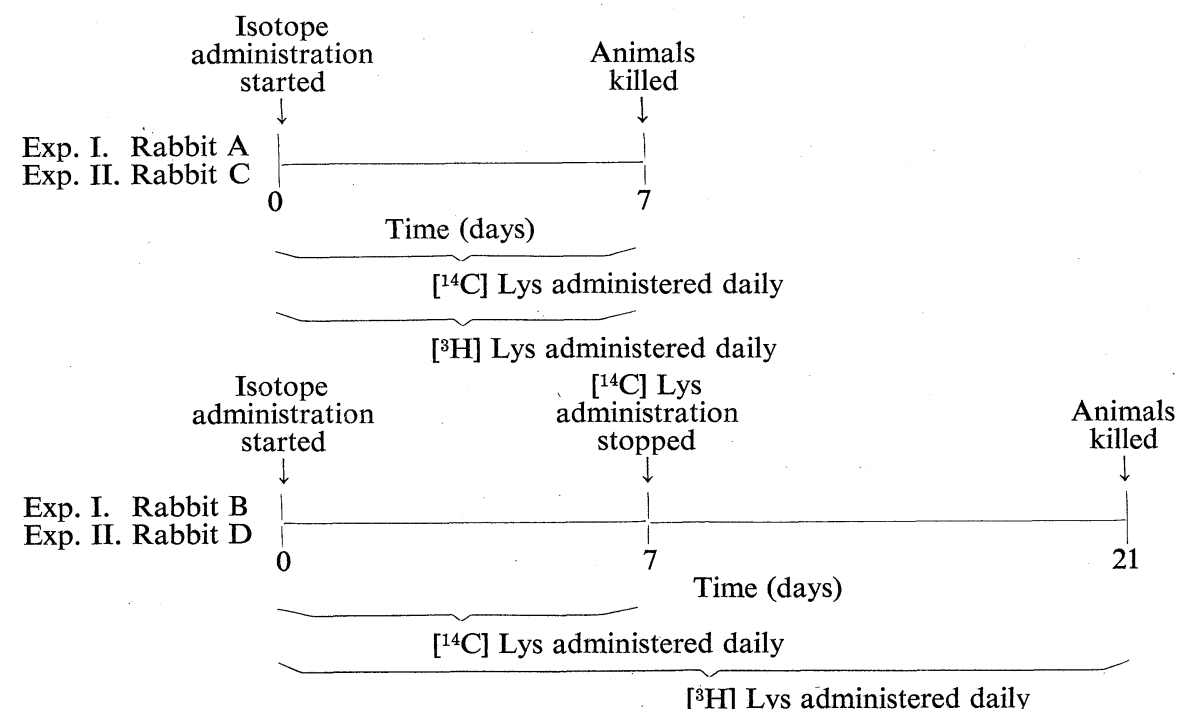

Scheme I. Design of isotope administration.

Preparation of proteins. Each animal was given sodium pentabarbital (50 mg) and $\alpha$-tubocurarine chloride $(3.0 \mathrm{mg})$ prior to exsanguination. Back and leg muscles were excised immediately, immersed in ice, corsely $(2 \mathrm{~mm})$ ground. Actin (13), tropomyosin (14) and troponin (15) were prepared through the I-Z-I brush (16), which consists of $\mathrm{Z}$ band with bilaterally attached thin filament. All experimental procedure for fractionation and purification of proteins was done in the cold $\left(0-1^{\circ} \mathrm{C}\right)$. 
The protein preparations were free of contaminants of protein from sources other than the myofibril because the proteins were prepared though the I-Z-I brush. Superprecipitation, ultracentrifugal analysis and gel filtration column chromatography were done to test the purity of the proteins (16). The actin had a little tropomyosin contamination and the troponin was contaminated by tropomyosin and actin in very small extent and the tropomyosin contained small amount of troponin.

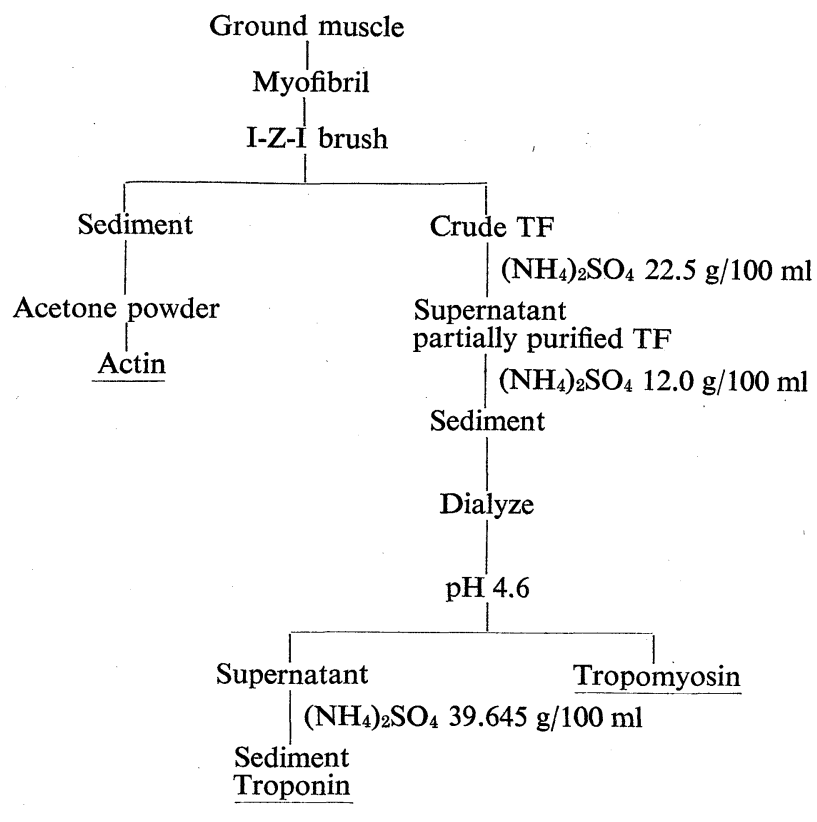

Scheme II. Outline of preparation of proteins.

Radioactivity measurement. The measurement of radioactivity is described in detail in the legend to Table 1.

\section{RESULTS AND DISCUSSION}

On the seventh day after the continuous administration of both ${ }^{3} \mathrm{H}$-lysine and ${ }^{14} \mathrm{C}$-lysine, the ratio of ${ }^{3} \mathrm{H}$ to ${ }^{14} \mathrm{C}$ was the same in actin and troponin in experiment I (Table 1, rabbit A), but in experiment II (Table 1, rabbit C), tropomyosin was somewhat different from other proteins (actin and troponin) even though the quenching efficiency of the other proteins was the same estimated by internal standard method.

The numerical value of the ratios of ${ }^{3} \mathrm{H} /{ }^{14} \mathrm{C}$ in experiment I (Table 1, rabbit A) is different from that in experiment II (Table 1, rabbit C). Different batches of labeled amino acid were used to make the labeled diets in the two different experi- 
Table 1. Relative turnover of thin filament proteins.

\begin{tabular}{|c|c|c|c|c|c|c|}
\hline & \multicolumn{5}{|c|}{ Experiment I } & \\
\hline & \multicolumn{3}{|c|}{ Rabbit $A^{a}$} & \multicolumn{3}{|c|}{ Rabbit $\mathrm{B}^{\mathrm{b}}$} \\
\hline & ${ }^{3} \mathrm{H} \mathrm{dpm}$ & ${ }^{14} \mathrm{C} \mathrm{dpm}$ & ${ }^{3} \mathrm{H} /{ }^{14} \mathrm{C}$ & ${ }^{3} \mathrm{H}$ dpm & ${ }^{14} \mathrm{C} \mathrm{dpm}$ & ${ }^{3} \mathrm{H} /{ }^{14} \mathrm{C}$ \\
\hline Actin & 2,899 & 673 & 4.3 & 5,416 & 604 & 9.0 \\
\hline Tropomyosin & - & - & - & 34,218 & 3,628 & 9.4 \\
\hline \multirow[t]{4}{*}{ Troponin } & 2,693 & 627 & 4.3 & 33,358 & 3,110 & 11 \\
\hline & \multicolumn{5}{|c|}{ Experiment II } & \\
\hline & \multicolumn{3}{|c|}{ Rabbit $C^{a}$} & \multicolumn{3}{|c|}{ Rabbit $D^{b}$} \\
\hline & ${ }^{3} \mathrm{H}$ dpm & ${ }^{14} \mathrm{C} \mathrm{dpm}$ & ${ }^{3} \mathrm{H} /{ }^{14} \mathrm{C}$ & ${ }^{3} \mathrm{H} \mathrm{dpm}$ & ${ }^{14} \mathrm{C} \mathrm{dpm}$ & ${ }^{3} \mathrm{H} /{ }^{14} \mathrm{C}$ \\
\hline Actin & 340 & 109 & 3.1 & 1,480 & 194 & 7.6 \\
\hline Tropomyosin & 2,998 & 1,058 & 2.8 & 10,992 & 1,368 & 8.0 \\
\hline Troponin & 2,983 & 959 & 3.1 & 7,806 & 875 & 8.9 \\
\hline
\end{tabular}

a Rabbit $\mathrm{A}$ and $\mathrm{C}$ received a mixture of ${ }^{3} \mathrm{H}(\mathrm{G})$-lysine $(100 \mu \mathrm{Ci} /$ day/rabbit $)$ and ${ }^{14} \mathrm{C}(\mathrm{U})$ lysine $(20 \mu \mathrm{Ci} /$ day/rabbit) during 7 days.

b Rabbit B and D received a mixture of ${ }^{3} \mathrm{H}(\mathrm{G})$-lysine $(100 \mu \mathrm{Ci} /$ day/rabbit $)$ and ${ }^{14} \mathrm{C}(\mathrm{U})-$ lysine $\left(20 \mu \mathrm{Ci} /\right.$ day/rabbit) during 7 days and subsequent 14 days ${ }^{3} \mathrm{H}(\mathrm{G})$-lysine $(100 \mu \mathrm{Ci} /$ day/rabbit) only.

One milliliter protein solution was precipitated by the addition of $1 \mathrm{ml}$ of $10 \%$ $(\mathrm{w} / \mathrm{v})$ trichloracetic acid and trapped on a glass fiber filter $(2.4 \mathrm{~cm})$. It was washed with $1 \mathrm{ml}$ of $10 \%(\mathrm{w} / \mathrm{v})$ trichloracetic acid, then with $0.5 \mathrm{ml}$ of $5 \%(\mathrm{w} / \mathrm{v})$ trichloracetic acid and finally with small amount of $1: 1$ ethanol-ether $(\mathrm{v} / \mathrm{v})$ solution. The glass fiber filter disc was dried under an infrared lamp and then dissolved in $2 \mathrm{ml}$ of "NCS" solubilizer (Amersham Searle) for $24 \mathrm{hr}$ at $36^{\circ} \mathrm{C}$ in the scintillation vail. Ten milliliters of toluene-based scintillation fluid (17) (5 g PPO, $0.3 \mathrm{~g}$ dimethyl POPOP/1-toluene) was added. Four vials were obtained from a protein sample and counted in a Nuclear Chicago Unilux II scintillation spectrometer. Each vial was counted four times for $10 \mathrm{~min}$ and average values were obtained. No difference in degree of quenching was found by an internal standard method. One hundred microliters ${ }^{3} \mathrm{H}$-toluene quenching standard $\left(2.26 \times 10^{5} \mathrm{disint} / \mathrm{min}\right)$ and $100 \mu$ liter of ${ }^{14} \mathrm{C}$-toluene quenching standard $\left(4.26 \times 10^{4} \mathrm{disint} / \mathrm{min}\right)$ were added separately to two vials of the same sample after counting and counted again.

Counting efficiencies were $39.3 \%$ for ${ }^{3} \mathrm{H}$ and $57.1 \%$ for ${ }^{14} \mathrm{C}$ with $15.1 \%$ spillover of ${ }^{14} \mathrm{C}$ with the ${ }^{3} \mathrm{H}$ channel. Spilling over of ${ }^{3} \mathrm{H}$ into the ${ }^{14} \mathrm{C}$ channel was $0.0125 \%$. Disintegrations per $\min { }^{3} \mathrm{H}$ and ${ }^{14} \mathrm{C}$ was calculated from the following equations:

$$
D_{\mathrm{H}}=\frac{0.571 N_{1}-0.15 N_{2}}{0.224} \quad D_{\mathrm{C}}=\frac{N_{2}}{0.571}
$$

$D_{\mathrm{H}}$ : disintegrations/min for ${ }^{3} \mathrm{H}$. $D_{\mathrm{C}}$ : disintegrations/min for ${ }^{14} \mathrm{C} . N_{1}$ : net counts/ min in ${ }^{3} \mathrm{H}$ channel. $\quad N_{2}$ : net counts/min in ${ }^{14} \mathrm{C}$ channel.

Ratios of disintegrations/min for ${ }^{3} \mathrm{H}$ and disintegrations/min of ${ }^{14} \mathrm{C}$ were calculated. Specific radioactivity was calculated by division of $D_{\mathrm{H}}$ and $D_{\mathrm{C}}$ by protein concentration of same lot used for measurement of radioactivity. Protein concentration was determined by the biuret method according to GoRnAll et al. (18). Bovine serum albumin was used as a standard. Overall relative standard error is less then $\pm 1.6 \%$. 
ments. The labeled solutions were prepared by the dilution of original $0.01 \mathrm{~N}$ $\mathrm{HCl}$ solution with $0.05 \%$ dehydroacetic acid sodium salt and the observed differences may be due to pipetting errors. If the counting efficiency and stability of labeling is the same in protein samples to be compared then the numerical value of the ratios should be the same in the protein in the same experiment.

Differences in the ratios of ${ }^{3} \mathrm{H}$ to ${ }^{14} \mathrm{C}$ among the proteins in rabbit $\mathrm{B}$ and in rabbit $\mathrm{D}$ are small but the order is reproducible in two experiments as seen in Table 1. The order of degree in relative ratios is as follows: troponin $>$ tropomyosin $>$ actin.

Specific radioactivity of ${ }^{3} \mathrm{H}$ in all the proteins examined increased almost proportionally with time at least during 21 days (Fig. 1). In the previous experiment (unpublished) with continuous feeding of ${ }^{14} \mathrm{C}$-lysine to rats, both the specific activity of free lysine in muscle and lysine residue of actin reached a plateau in two weeks. In rabbits much more time would be needed to reach the plateau level both in the specific radioactivity of free lysine in muscle and lysine residue of actin. Maximum level of isotope saturation will appear after 21 days. During 14 days after the discontinuation of ${ }^{14} \mathrm{C}$, the specific radioactivity of ${ }^{14} \mathrm{C}$ in actin, tropomyosin and troponin does not decrease, but maintains the approximate same level (Fig. 1).

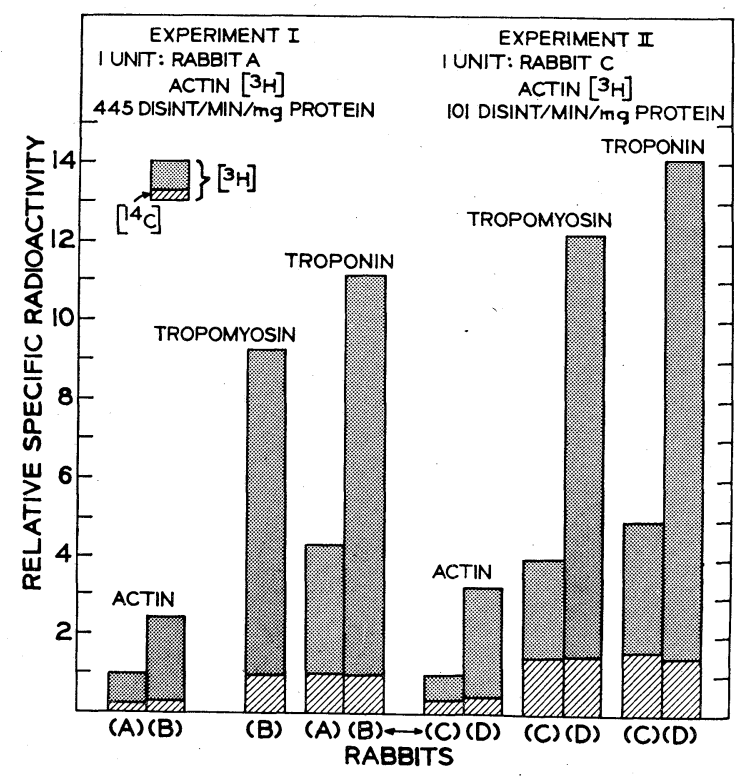

Fig. 1. Relative specific radioactivity of proteins. For the detail of the experiments, see legend in Table 1.

Previous results showed that after a duration of 8 days administration of ${ }^{14} \mathrm{C}$-chlorella protein acid hydrolyzate to rats, the specific radioactivity of actin 
did not change during 20 days, while the specific radioactivity of blood-globin increased and that of serum albumin decreased rapidly (19). When the protein is stable during the life span, the radioactivity remaining after the discontinuation of the radioisotope administration causes an increase in the specific radioactivity of the protein. It is reasonable to say that the plateau would represent the unstable nature of the proteins. A high degree of reutilization might be occurring in the tissue and therefore prevent the decrease of specific radioactivity of the protein which has the slow turnover rate. The same pattern of the change of specific radioactivity of ${ }^{14} \mathrm{C}$ and ${ }^{3} \mathrm{H}$ in the proteins (Fig. 1) would be resultant from the same type of turnover of actin, tropomyosin and troponin.

The specific radioactivity of the protein (disint $/ \mathrm{min} / \mathrm{mg}$ protein) at a certain time point is determined by the turnover rate and isotope saturation level and content of lysine residue. The lysine content of troponin and tropomyosin is about twice that of actin (20). Even if the specific radioactivity of actin is multiplied by two in order to compare it with the other proteins, the value for specific activity of actin is low. If the maximum isotope saturation level and rate of isotope saturation of the free amino acid pool from which proteins are synthesized are the same, then the turnover rate of the protein could be compared by the specific radioactivity of the protein at a certain time point or approximately from the slope along the time axis in the continuous isotope administration method. In this experiment, there is no data about the precursor, so it is not reasonable to deduce that actin has a lower turnover rate than tropomyosin and troponin from the level of specific radioactivity on the slope.

In the continuous isotope administration method, the factors for determining the shape of the specific radioactivity time-curve of the proteins in the steady state would be metabolic turnover rate, type of metabolic turnover, degree of reutilization, maximum isotope saturation level of the proteins and kinetic behavior of the precursor amino acid pool. We could know whether proteins turnover at the same rate or not by comparing with the specific radioactivity-time curves of the proteins, but a number of time points are required to construct the specific radioactivitytime curves. Even though these factors described above would also determine the ratios of ${ }^{3} \mathrm{H}$ to ${ }^{14} \mathrm{C}$ in the continuous double isotope method it may be reasonable to assume that actin, tropomyosin and troponin have the same turnover type as already mentioned and the effect of different isotope saturation level was avoided by taking the ratio of ${ }^{3} \mathrm{H}$ to ${ }^{14} \mathrm{C}$ in the same protein sample in the same animal. Continuation of ${ }^{14} \mathrm{C}$ for 7 days might avoid the effect of different position of the peaks along time axis in different proteins. There is no evidence but it may be reasonable to consider that the larger quantity of ${ }^{14} \mathrm{C}$ left in the tissue would cancel the small difference in degree or reutilization, especially for the proteins compared in the same cell organelle, the thin filament.

When the ratios of ${ }^{3} \mathrm{H}$ to ${ }^{14} \mathrm{C}$ are the same in the proteins in a cell organelle, the proteins have same turnover rate. When the ratio of ${ }^{3} \mathrm{H}$ to ${ }^{14} \mathrm{C}$ is different 
for various proteins in a cell organelle, then the proteins have different turnover rate. There was a difference in the ratio of ${ }^{3} \mathrm{H}$ to ${ }^{14} \mathrm{C}$ among thin filament proteins. The ratio of tropomyosin was greater than that of actin. This would mean that tropomyosin turned over faster than actin. This conclusion is in accordance with the result of VelicK (5), who estimated that the half-life of actin was 67 days and that of tropomyosin was 27 days. Troponin had the fastest turnover among the thin filament protein which we examined in this experiment. Even though the severe significance of the different turnover rate might be questioned suffering from the heterogeneous construction of the troponin (21-23) and from the cross contamination among the myofibrillar proteins, the data is consistent with an asynchronous assembly and degradation of the proteins of the thin filament in skeletal muscle of the rabbit.

This work was supported by the College of Agricultural and Life Sciences, University of Wisconsin, Madison and by U.S. Public Health Service Grant FD 00107-13. Muscle Biology Manuscript No. 18.

We thank Dr. N. J. Benevenga, Dr. E. J. Briskey, Dr. A. E. Harper and Dr. R. W. Swick for helpful discussions.

\section{REFERENCES}

1) Funabiki, R. and CAssens, R. G., Nature, New Biology, 236, 249 (1972).

2) Neuberger, A. Brit. Med. Bull., 8, 210 (1952).

3) Dreyfus, J. C., Kruh, J., and ShapirA', G., Biochem. J., 75, 574 p (1960).

4) Funabiki, R. and Kandatsu, M., J. Biochem. (Tokyo), 64, 717 (1968).

5) Velick, S. F., Biochim. Biophys. Acta, 20, 228 (1956).

6) McManus, I. R. and Mueller, H., J. Biol. Chem., 241, 5967 (1966).

7) Funabiki, R. and Kandatsu, M., J. Agr. Chem. Soc. Japan (in Japanese), 39, 157 (1965).

8) Funabiki, R. and Kandatsu, M., J. Agr. Chem. Soc. Japan (in Japanese), 39, 501 (1965).

9) Millward, D. J., Clin. Sci., 39, 577 (1970).

10) Ebashi, S., Endo, M., and Ohtsuki, I., Quart. Rev. Biophys., 2, 351 (1969).

11) Schimke, R. T., Ganshow, R., Doyle, D., and Arias, I. M., Fed. Pro., 27, 1223 (1968).

12) Rogers, Q. R. and HARPER, A. E., J. Nutrition, 87, 267 (1965).

13) Mommaerts, W. F. H. M., J. Biol. Chem., 198, 445 (1952).

14) Arai, K. and Watanabe, S., J. Biol. Chem., 243, 5670 (1968).

15) Ebashi, S., Kodama, A., and Ebashi, F., J. Biochem. (Tokyo), 64, 465 (1968).

16) Fukazawa, T., Briskey, E. J., and Mommaerts, W. F. H. M., Arch. Biochem. Biophy., 137, 500 (1970).

17) PAPKIn, E., International J. Appl. Radiation and Isotopes, 15, 69 (1964).

18) Gornall, A. G., Bardawill, G. J., and David, M. M., J. Biol. Chem., 177, 751 (1949).

19) Funabiki, R. and Kandatsu, M., J. Agr. Chem. Soc. Japan (in Japanese), 40, R69 (1966).

20) Maruyama, K. and Ebashi, S., in E. J. Briskey, R. G. Cassens and B. B. Marsh (Editors), The Physiology and Biochemistry of Muscle as a Food, The University of Wisconsin Press, Madison, Milwaukee and London, Vol. 2, p. 373 (1970).

21) Greaser, M. L. and Gergely, J., J. Biol. Chem., 246, 4226 (1971).

22) Wilkinson, J. M., Perry, S. V., Coele, H., and Trayer, I. P., Biochem. J., 124, 55p. (1971).

23) Ebashi, S., Wakabayashi, T., and Ebashi, F., J. Biochem. (Tokyo), 69, 441 (1971). 